Thorax (1969), 24, 595.

\title{
Prevention of reflux from the stomach into the oesophagus
}

\author{
G. KENTHARRISON AND R. NORTON \\ From St. Thomas' Hospital, London, S.E.1
}

\begin{abstract}
The results of operating upon 51 patients suffering from gastric reflux are described. The only apparently effective step in the operation was to fix a portion of the oesophagus in the abdominal cavity. The clinical and radiological studies indicate that the lower oesophagus in the abdomen acts as a valve.
\end{abstract}

The normal mechanism of preventing the reflux of gastric contents into the oesophagus has been studied intensely, but no hypothesis is so easy to prove and understand that it has obtained universal acceptance (Allison, 1956 ; Barrett, 1954 ; Botha, Astley, and Carré, 1957 ; Marchand, 1955). Methods of prevention of reflux which has resulted in oesophageal pathology are therefore variable.

Reflux is often shown by a barium meal to be associated with a hiatus hernia, and the presence of a length of oesophagus below the diaphragm acting as a flap valve has been thought to play some part in the normal mechanism for preventing reflux (Dornhorst, Harrison, and Pierce, 1954; Creamer, Harrison, and Pierce, 1959 ; Johnson, 1966).

Most procedures designed to prevent reflux include securing a length of oesophagus below the diaphragm, but at the same time the diaphragm hiatus is tightened around the oesophagus and the oesophagus is made to enter the stomach at an acute angle.

That reflux can occur without a hiatus hernia demonstrated by barium swallow has been accepted (Belsey, 1966). It is possible that a minimum length of oesophagus in the abdomen is required to prevent reflux and that when this is absent reflux can occur without a full-blown hernia being present. There is an area of thought and findings here which is not clear. A hernia may be demonstrated one day and not the next. With the hand in the abdomen and the chest open, the upper end of the stomach can be pushed into the chest through the hiatus. It is seen to move like a piston in a cylinder of surrounding tissue in the normal and abnormal.

An operation is described which appears only to fix a length of oesophagus in the abdominal cavity. The results are described below. They indicate that a length of oesophagus in the abdominal cavity acts as a valve on its own merits under these conditions, without an acute angle of entry into the stomach and without narrowing of the hiatus.

\section{OPERATIVE DETAILS}

The left side of the chest is opened through the seventh or eighth space. The lower oesophagus and the antero-lateral peritoneal fold are exposed. A thread marker is placed where the oesophageal tube changes to the gastric sac. This is usually within half an inch $(12.7 \mathrm{~mm}$.) of the tip of the fold (Fig. 1).

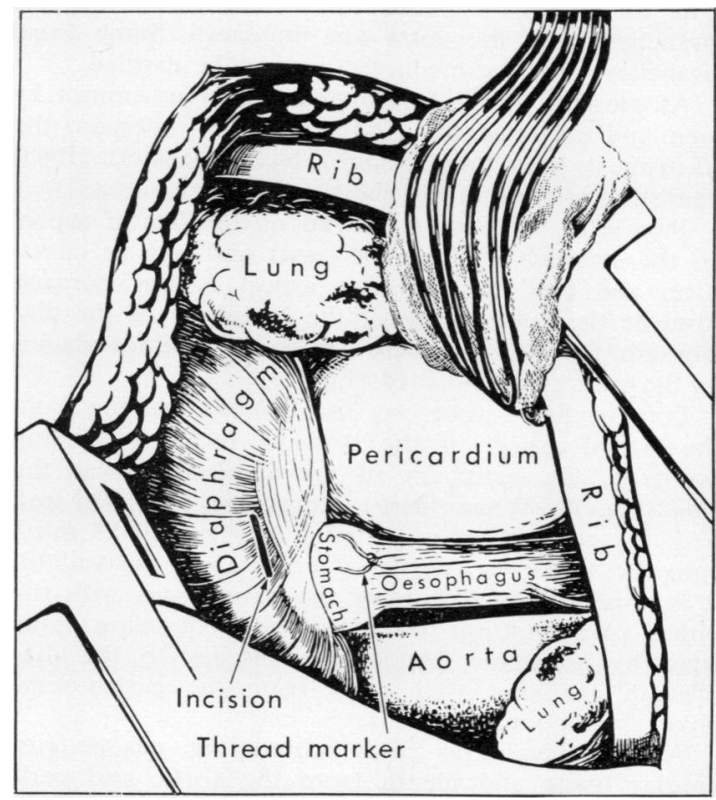

FIG. 1. Shows a small hernia, the thread marker, and the site of incision in the diaphragm. 
The diaphragm is opened in its lateral aspect by making a small incision through the muscle just lateral to the central tendon, about halfway between the anterior and posterior parts of the diaphragm as it presents. This opening is enlarged by tearing the muscle as in a McBurney incision. The opening is made large enough to allow the hand to enter the abdomen. The stomach, pylorus, and gall bladder are palpated.

The stomach and oesophagus are freed from the hiatus. The stomach is then pulled downwards to bring the oesophagus into the abdomen, and the object is to have $\frac{3}{4}$ to 1 in. $(19-25 \mathrm{~mm}$.) of oesophagus seen below the hiatus with moderate tension (Fig. 2).

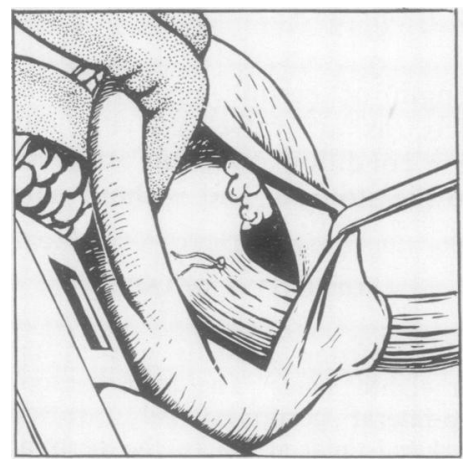

FIG. 2. Shows a good inch of oesophagus in the abdomen.

The oesophagus is freed up to the hilum, but the branches from the aorta are preserved. Some vagal branches from the mediastinum may be divided.

At present, if this length of oesophagus cannot be seen and encircled by a finger, in the abdomen, the gastropexy is abandoned and a Nissen-Rossetti (1963) operation is done in the chest.

Two Allis forceps are placed on the lateral aspect of the stomach towards the lesser and greater curvatures and used to push this aspect of the stomach towards the lateral edge of the periphery of the diaphragm. By adjusting these forceps the line for placing of the sutures is indicated (Fig. 3).

Four or five sutures are then placed, passing from the lateral aspect of the stomach to corresponding points in the periphery of the diaphragm near the ribs (Fig. 4). When these sutures are tightened and tied, the oesophagus is pulled $\frac{3}{4}$ to $1 \mathrm{in}$. (19-25 mm.) into the abdominal cavity. If omental fat is available it is applied to this part of the oesophagus with the object of preventing this soft tube from being made rigid by adhesions. Anchoring stitches to the diaphragm are kept well away from the gastro-oesophageal junction.

Above the hiatus and behind the oesophagus, areolar tissue and pleura from the aortic and pericardial regions are sutured together to discourage herniation of bowel into the chest. Two or three

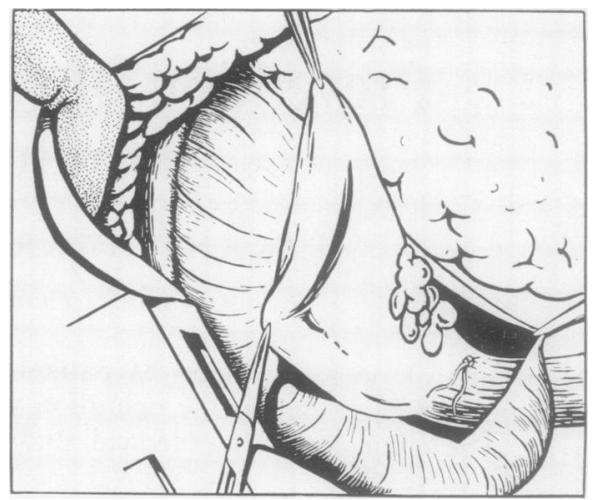

FIG. 3. Estimated line for sutures in the stomach.

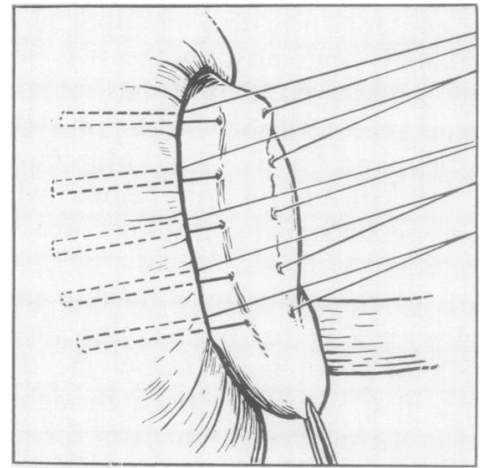

FIG. 4. Subserosal sutures in the stomach and suture in the diaphragm.

sutures are placed between the anterior and laterat aspects of the oesophagus and the pleura at the edge of the hiatus for the same reason.

The oesophagus now enters the stomach like 8 chimney enters the top of a house. The hiatus propes remains wide open. There is no constriction of the oesophagus.

\section{RESULTS}

The description, a 'technically satisfactory operaf tion', indicates that $\frac{3}{4}$ in. (19 $\mathrm{mm}$.) or more of oesophagus was fixed below the anterior edge o the hiatus with moderate tension. A 'technically unsatisfactory operation' indicates that less oeso phagus than this was fixed below the hiatus, of that marked tension was required to hold it, wha ever the length.

Between 1961 and 1965, 42 patients had preํํำ and post-operative barium meals. Before opera帝 tion they had symptoms of reflux, includin difficulty in swallowing, and they showed reflun of barium. In 35 of these patients no reflux was 
seen in post-operative barium meals. All these had technically satisfactory operations. Of the other seven in whom reflux was demonstrated postoperatively, four had technically satisfactory operations. The other three had unsatisfactory operations (Table I). Thus in 39 cases a satisfac-

\section{T A B L E I}

RESULTS OF BARIUM MEAL FOLLOW-UP IN 42

\begin{tabular}{|c|c|c|c|}
\hline & $\begin{array}{c}\text { No. } \\
\text { of } \\
\text { Patients }\end{array}$ & $\begin{array}{c}\text { No } \\
\text { Post-op. } \\
\text { Barium } \\
\text { Reflux }\end{array}$ & $\begin{array}{l}\text { Post-op. } \\
\text { Barium } \\
\text { Reflux }\end{array}$ \\
\hline $\begin{array}{l}\text { Technically satisfactory operation } \\
\text { Technically unsatisfactory opera- } \\
\text { tion }\end{array}$ & $\begin{array}{r}39 \\
3\end{array}$ & $\begin{array}{r}35 \\
0\end{array}$ & $\begin{array}{l}4 \\
3\end{array}$ \\
\hline Total & 42 & 35 & 7 \\
\hline
\end{tabular}

tory operation was performed, which was shown by barium meals to have prevented reflux in 35 cases. No hernia was demonstrated post-operatively in the 42 cases.

The average length of follow-up in the 42 cases was 2 years and 3 months, ranging from just over 1 month in three cases up to 6 years for two cases without barium reflux.

Advantage was taken of this opportunity to assess this operation from a symptomatic point of view (Table II).

This illustrates some variation between the radiological findings and the symptoms (Table III). After operation five of these 42 patients described symptoms of reflux; four of these were much less than before operation. The remaining one had un-

T A B L E I I

RESULTS OF CLINICAL FOLLOW-UP IN 42 PATIENTS

\begin{tabular}{|c|c|c|c|c|c|}
\hline & & & $\begin{array}{l}\text { No. of } \\
\text { Patients }\end{array}$ & $\begin{array}{c}\text { No } \\
\text { Post-op. } \\
\text { Reflux } \\
\text { Symptoms }\end{array}$ & $\begin{array}{c}\text { Post-op. } \\
\text { Reflux } \\
\text { Symptoms }\end{array}$ \\
\hline \multicolumn{3}{|c|}{$\begin{array}{l}\text { Technically satisfactory operation } \\
\text { Technically unsatisfactory opera- }\end{array}$} & & & \\
\hline \multirow[t]{2}{*}{ tion $\quad \ldots$} & . & $\ldots \quad \ldots$ & 3 & 2 & 1 \\
\hline & $\ldots$ & . & 42 & 37 & 5 \\
\hline
\end{tabular}

T A B L E I I I

COMPARISON OF BARIUM MEAL AND CLINICAL

\begin{tabular}{|c|c|c|c|}
\hline & $\begin{array}{c}\text { No Post-op. } \\
\text { Reflux } \\
\text { Symptoms }\end{array}$ & $\begin{array}{c}\text { Post-op. } \\
\text { Reflux } \\
\text { Symptoms }\end{array}$ & Total \\
\hline $\begin{array}{l}\text { No post-op. barium reflux } \\
\text { Post-op. barium reflux }\end{array}$ & $\begin{array}{r}31 \\
6\end{array}$ & $\begin{array}{l}4 \\
1\end{array}$ & $\begin{array}{r}35 \\
7\end{array}$ \\
\hline Total & 37 & 5 & 42 \\
\hline
\end{tabular}

changed symptoms following a technically unsatisfactory operation. This was the only one of these four to have barium reflux.

Of the seven patients shown to have barium reflux post-operatively, six had no corresponding symptoms. Two of these six had had technically unsatisfactory operations.

A further nine patients who had symptoms of reflux and showed barium reflux were operated on during the same period. Post-operative barium studies were not possible. Clinical follow-up for an average period of two years showed one of these nine to have symptoms attributable to reflux. All nine had had technically satisfactory operations (Table IV).

T A B L E I V

PATIENTS WITH CLINICAL FOLLOW-UP ONLY

\begin{tabular}{l|c|c|c}
\hline & $\begin{array}{c}\text { No. } \\
\text { of } \\
\text { Patients }\end{array}$ & $\begin{array}{c}\text { No } \\
\text { Post-op. } \\
\text { Reflux } \\
\text { Symptoms }\end{array}$ & $\begin{array}{c}\text { Post-op. } \\
\text { Reflux } \\
\text { Symptoms }\end{array}$ \\
\hline $\begin{array}{c}\text { Technically satisfactory operation } \\
\text { Technically } \\
\text { tion unsatisfactory opera- }\end{array} .$. & 9 & 8 & 1 \\
\hline
\end{tabular}

Combining this group of nine with the previous group of 42 , a total of 48 patients had technically satisfactory operations. Five of these 48 had some symptoms of reflux post-operatively (Table V).

\section{T A B L E V}

RESULTS OF CLINICAL FOLLOW-UP OF THE TWO GROUPS (9 AND 42) COMBINED

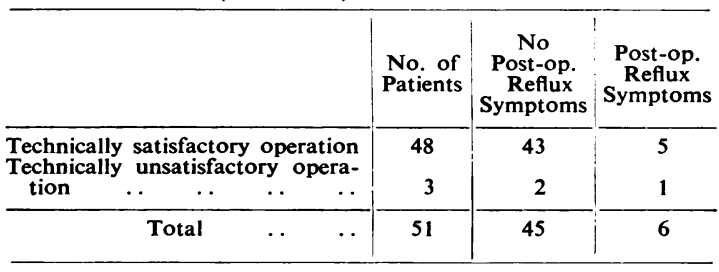

\section{DISCUSSION}

The results of this operation compare favourably with the results of several other operations. It was developed with the object of elucidating the mechanism of reflux prevention by a clinical test in which only one of the accepted factors was manipulated. This factor is the fixing of a definite length of oesophagus in the abdominal cavity. This was justified by the fact that restoration of the oesophagus to the abdomen is a common factor in other operations and by the evidence of experimental work.

Boerema (1958) eliminated the factor of hiatus narrowing but retained the factor of angle of 
entry of oesophagus into stomach as well as placing the oesophagus in the abdomen.

Thus clinical support is given that the lower oesophagus in the abdomen acts as a valve on its own merits.

We wish to thank Dr. B. Creamer and Dr. J. W. Pierce and the physicians and surgeons who referred patients ; Dr. W. D. Wylie for patience in anaesthesia ; and Miss C. J. Dewe for the drawings.

\section{REFERENCES}

Allison, P. R. (1956). Function and dysfunction of the cardia. Bull. Johns Hopk. Hosp., 99, 182.
Barrett, N. R. (1954). Hiatus hernia-a review of some controversiaf points. Brit. J. Surg., 42, 231.

Belsey, R. (1966). Functional disease of the esophagus. J. thorac cardiovasc. Surg., 52, 164.

Boerema, I. (1958). Gastropexia anterior geniculata for sliding hiatu尺 hernia and for cardiospasm. J. int. Coll. Surg., 29, 533.

Botha, G. S. M., Astley, R., and Carré, I. J. (1957). A combinedै cineradiographic and manometric study of the gastro-oesophageatjunction. Lancet, 1, 659.

Creamer, B., Harrison, G. Kent, and Pierce, J. W. (1959). Further observations on the gastro-oesophageal junction. Ibid., 14, 132.

Dornhorst, A. C., Harrison, G. Kent, and Pierce, J. W. (1954)心 Observations on the normal oesophagus and cardia. Lancet, 695.

Johnson, H. Daintree (1966). Active and passive opening of the cardia and its relation to the pathogenesis of hiatus hernia. Gut, 7, 392

Marchand, P. (1955). The gastro-oesophageal 'sphincter' and ther mechanism of regurgitation. Brit. J. Surg., 42, 504.

Nissen, R., and Rossetti, M. (1963). Surgery of the cardia ventriculic Ciba Symp., 11, 195. 